Article

\title{
Eric Perl's Theophanism: An Option for Agnostics?
}

\author{
Travis Dumsday
}

Department of Philosophy \& Religious Studies, Concordia University of Edmonton, Edmonton, AB T5B 4E4, Canada; travis.dumsday@concordia.ab.ca

Received: 1 May 2020; Accepted: 15 May 2020; Published: 19 May 2020

check for updates

\begin{abstract}
Recent work in analytic philosophy of religion has seen increased interest in nontheistic, but still non-naturalist (indeed, broadly religious) worldview options. J.L. Schellenberg's Ultimism has been among the most prominent of these. Another interesting option that has yet to receive much attention is the Theophanism advocated by the Neoplatonism scholar Eric Perl. In this paper, I summarize Perl's theophanism (which he describes as being neither theistic nor atheistic) and assess it on two fronts: (a) whether it might be an acceptable philosophical option for agnostics, specifically, and (b) to what extent it is independently defensible philosophically.
\end{abstract}

Keywords: agnosticism; atheism; theism; God; Neoplatonism; Perl; Eric; orthodoxy

\section{Introduction}

The subfield that is analytic philosophy of religion remains focused primarily on issues pertaining to two competing perspectives or worldviews: metaphysical naturalism (MN) and Judeo-Christian theism (JCT). Insofar as MN maintains that the only irreducible kinds of reality are essentially physical in character (perhaps spacetime plus fundamental particles or fields), it is seen today as inherently atheistic. ${ }^{1}$ JCT stands as something of a polar opposite, affirming not only a personal, necessarily existent and spiritual OmniGod (a divinity who is essentially omnipotent, omniscient, and omnibenevolent) but also the reality of other irreducibly spiritual entities (like human souls) and nonphysical causal processes (like miracles). Thus, the dispute between MN and JCT involves a good deal more than just the debate over the existence of God, even if that remains the core dividing line between them. The fact that they still receive the lion's share of attention in the analytic literature is clear from a perusal of recent volumes of the major journals in the field, and on occasion is explicitly adverted to. McLean (2015, p. 17), for instance, writes: "So I propose that, in considering theism, we think of the orthodox Christian story ... and that, in considering atheism, we think of naturalistic atheism ... I suppose that many Western philosophers, and others, would regard those two views of the world as chief contenders in the metaphysical debate-as the two leading philosophical live options, as it were."

That said, alternative perspectives or worldviews are receiving more attention in this literature than they used to; increasingly, books and articles on alternative forms of theism are sharing space within analytic philosophy of religion (alternatives like pantheism and panentheism), as are works on assorted forms of nontheistic non-naturalism (NTNN) - i.e., views that either affirm atheism or

1 The old Epicurean idea of real but purely physical gods is no longer taken seriously in a contemporary philosophical or religious context, and so metaphysical naturalism is regarded as entailing atheism. The one major exception among current world religions is Mormonism, with its florid physicalist polytheism. Accessible accounts of Mormon ontology may be found in Bushman (2008) and Givens (2014). 
remain neutral on the issue, while at the same time, denying the truth of MN. Examples of NTNNs would include panpsychism, animism, Ultimism, and Ietsism. ${ }^{2}$

The increased attention now being given to these alternatives to MN and JCT may prompt some further reflections by agnostics. First, provided that agnosticism is understood as involving an epistemic claim pertaining to the Judeo-Christian God (and typically, it is thus understood), ${ }^{3}$ then one cannot remain an agnostic while affirming the truth of pantheism or panentheism. Proponents of those alternative theisms understand themselves either as putting forward a replacement for JCT that is incompatible with JCT (this is almost always the case for self-identified pantheists and is often the case for panentheists) or as putting forward a philosophical theology that is different from JCT as typically understood but that still falls within the strictures of Jewish or Christian orthodoxy (as is sometimes the case with panentheists). Whether pantheism and panentheism are seen as incompatible with JCT (thus entailing JCT's falsity) or seen as modified formulations of JCT (thus entailing its truth), the agnostic cannot affirm either of them while remaining agnostic.

Second, and more relevant for our purposes, one might remain an agnostic in good standing while, at the same time, entertaining or even affirming any one of the aforementioned forms of NTNN. After all, agnosticism is consistent with a convinced rejection of MN. An agnostic could accept panpsychism or animism or Ultimism or Ietsism while retaining her agnosticism. Moreover, she might seek to inquire into these views either on account of their standalone philosophical interest or on account of their possible relevance to the larger assessment of JCT. For, if panpsychism (for instance) were shown to be true, then MN would thereby be shown false, and the falsity of MN could rationally be seen as raising the probability of JCT at least marginally. And there could be other features of panpsychism that would be indirectly relevant to the assessment of JCT; perhaps panpsychism could

2 A helpful entry point into all these views may be found in the new anthology edited by Buckareff and Nagasawa (2016). Some additional useful sources: on pantheism (very roughly, the view that God = the cosmos, or that there is an overarching holistic unity of all natural things and that this unity is divine) see for instance (Levine 1994, 2007), Oppy (1997), Sprigge (1997), and Steinhart (2004); on panentheism (very roughly, the view that God is not identical with the cosmos but that there is some sort of mereological or containment or other intimate relationship between them, with an analogy often invoked to the effect that God is to the cosmos as the human soul is to the human body), see for example Burns (2019), Clayton (2004), CooCooper (2006), Crisp (2019), (Dumsday 2019a, 2019b), Gocke (2013), Jantzen (1984), (Lataster 2014, 2015), Mullins (2016), and Stenmark (2019); on panpsychism (very roughly, the view that all physical entities (or all physical entities meeting certain compositional criteria) are either conscious or proto-conscious), see Strawson (2006), Goff (2019), and Goff et al. (2017) - also, note that while some advocates of the view consider panpsychism to be compatible with MN, I am inclined to disagree, insofar as panpsychism posits that irreducible reality incorporates the nonphysical; in the analytic philosophy of religion literature, there is not much available specifically on animism (very roughly, the view that all physical entities are ensouled or inhabited by spiritual entities), but see Steinhart (2017) for an interesting recent treatment and see Yamakage (2006) for a compelling articulation of a version of animism from a religious perspective. Ultimism (the theory that there exists a metaphysically, axiologically, and soteriologically ultimate reality of some sort) has, by contrast, received a great deal of attention in the literature. A pragmatic commitment to actively entertaining (without believing in) Ultimism is one component of the broader, systematic nontheistic non-naturalist philosophy of religion developed by (Schellenberg 2005, $2007,2009,2013$ ). Ietsism (the theory that there exists a soteriologically transcendent reality that may or may not also be axiologically or metaphysically transcendent) is a modification of Ultimism defended by Elliott (2017) and designed to be even more epistemically modest and, thus, less committal with regard to propositional content.

3 While cognizant of competing definitions, for the moment I will take agnosticism as an epistemic (rather than psychological or pragmatic) doctrine with the following content: at present, the most rational position for the normal inquirer to take regarding the question of theism is that she does not know (a) whether the God of JCT exists, does not know (b) whether the objective evidential probabilities lie heavily in one direction or the other, and does not know (c) whether the epistemic situation is liable to change much. This formulation of agnosticism is intended to be modest. For instance, it leaves open the possibility that there might be privileged individuals (mystics or prophets, etc.) with access to religious knowledge unavailable to the average person (the "normal inquirer"); it leaves open the possibility that the general epistemic situation might have been different in the past or might change in the future; it remains noncommittal regarding the question of what the evidential probabilities really are (in contrast to more ambitious agnosticisms claiming to know that the probabilities in favor of theism and atheism are evenly balanced or that the probabilities are necessarily inscrutable, etc.); it is best understood as a descriptive claim, to the effect that it is making a claim about the average inquirer's actual present state of knowledge, as opposed to a modal or a normative claim about what such an inquirer can know our ought to claim to know. As an epistemic rather than pragmatic understanding of agnosticism, this definition also leaves open the question of how one ought to live out the view (i.e., whether one ought to live as if there were a God, engaging in prayers and other forms of religious practice, or instead, to live as if there were no God). It also takes no stance on whether the agnostic can or should rationally hope for the truth of theism or atheism. 
be seen as providing for the first premise of a teleological argument, with an intelligent designer being invoked to explain how finite centers of consciousness (or proto-consciousness) come to be associated with quantities of matter (much as substance dualists sometimes argue that God is needed to explain the contingent connection between human minds and brains, as in (Swinburne 2010, chp. 5)). Alternatively, perhaps panpsychism could somehow be employed in a premise of atheological reasoning. The upshot: there is no reason why an agnostic qua agnostic need reject any of these NTNNs, and there may be reasons why an agnostic qua agnostic should actively inquire into them, insofar as they may allow for new progress-progress either away from agnosticism and towards a confirmed atheism or progress away from agnosticism and towards confirmation that the God of JCT exists.

Given the potential value to agnostics of careful consideration of NTNNs, it is worth asking: are there any other philosophically interesting versions of NTNN, versions which have received little or no attention in the analytic philosophy of religion literature? Unsurprisingly, there are, and so, for this Special Issue of Religions dealing with the topic of agnosticism, I wish to highlight one of these and to consider it specifically in relation to agnosticism. Namely, I wish to examine a version of NTNN called theophanism. This is an historically grounded theory expounded and defended by a prominent scholar of Neoplatonism, Eric Perl. The label derives from the Greek "theophany", meaning divine manifestation or appearance, which is also the lead title of the 2007 book in which Perl first laid out his theory in detail. Perl describes theophanism as being neither theistic nor atheistic. My goals in what follows are to provide a summary of theophanism (a task taken up in the next section of the paper) and, then, to assess it (the task of the final section). That assessment will address two issues: (a) whether theophanism might be an acceptable philosophical option for agnostics specifically and (b) to what extent theophanism is independently defensible philosophically.

\section{Theophanism: A Summary}

Perl's theophanism is a systematic form of NTNN in two senses of "systematic": in the sense of being laid out with attention to clarity and logical rigor and in the sense of being situated within a larger philosophical system. That system is a particular version or interpretation of Neoplatonism. Perl (2007, p. 2) understands Neoplatonism as no mere historical artifact but, rather, as "a profound and well-argued understanding of reality and as the most promising resource to which we may turn in our present intellectual and cultural predicament". Perl discerns in this system a coherent tradition of thought extending from Plato himself up through the sixth century AD, culminating in the work of the anonymous Syrian monastic who wrote under the pen name of "Dionysius the Areopagite". 4 According to Perl, this Neoplatonic system on display in Dionysius' writings ${ }^{5}$ incorporates theophanism.

In more recent works, Perl $(2014$, chp. 5; 2019) also makes the ambitious argument that this same broadly integrated, coherent Neoplatonic system can be seen as extending still further in time, up through the high Middle Ages and into the thought of Thomas Aquinas. This yields an interpretation of Aquinas' own system that is quite different from that adopted by most Thomists today. Though of much interest, this aspect of Perl's scholarship is liable to be particularly controversial, and I will leave it to one side in what follows. Moreover, being neither an historian of philosophy nor a specialist in Neoplatonism, I have nothing useful to say regarding the accuracy of Perl's exegesis of Dionysius or of the philosophical predecessors (chiefly, Plato, Plotinus, and Proclus) that Perl sees as informing Dionysian Neoplatonism. As such, I will venture no opinions concerning it. My interest is

4 Since this unknown author was using "Dionysius" as a pseudonym, modern scholars often refer to him as "Pseudo-Dionysius the Areopagite". I will follow Perl's convention of dropping the "pseudo", the use of which he rightly notes (Perl 2007, p. 115) is both stylistically awkward and potentially pejorative in connotation.

5 The complete Dionysian corpus is relatively small, consisting of only five works (On the Divine Names, On the Celestial Hierarchy, On the Ecclesiastical Hierarchy, On Mystical Theology, and the Epistles) that collectively occupy a mid-sized volume in modern English translation. Probably the most commonly used such translation is that of Luibheid (1987), though Perl (2007, p. ix) expresses reservations about its faithfulness as a rendering of the original Greek, and when quoting Dionysius he employs his own original translations. 
with Perl's theophanism as a form of NTNN, and while a proper overview requires placing it within its systematic context (that of Dionysian Neoplatonism as interpreted by Perl), it does not require either a defense or a critique of the historical theses Perl affirms regarding that context.

On then to the central commitments of Dionysian Neoplatonism. Given space constraints, I cannot get into all of the components of this system as laid out by Perl, so I will restrict coverage to twelve core propositions that lead into and inform theophanism. While the numbering is my own, I believe this ordering and logical progression accurately reflect Perl's own presentation and his claims regarding their conceptual connections. Let us first lay them out succinctly and then consider each in turn:

Proposition \#1: being = intelligibility

Proposition \#2: Platonic Forms are real

Proposition \#3: individual material objects are not real; they are merely the appearances or manifestations of beings (in this case, Forms)

Proposition \#4: MN is false

Proposition \#5: the realm of being involves complexity and multiplicity, determinate identity, and difference (implying the finitude of every being and the falsity of monism)

Proposition \#6: being/intelligibility is dependent on the Good

Proposition \#7: Forms = ideas (i.e., the Forms are beings, and they are also the contents of a super-Mind called Intellect ("Nous"))

Proposition \#8: being/intelligibility is dependent on the One

Proposition \#9: the Good = the One

Proposition \#10: the Good/One is not intelligible (i.e., it is not a being and, so, is not knowable by any intellect)

Proposition \#11: the Good/One = God (though not the God of JCT, at least as that God is typically understood)

Proposition \#12: all beings are manifestations or appearances of the Good/One/God (i.e., theophanism is true)

The first proposition is an identity claim: being = intelligibility. Perl $(2007$, p. 5) writes: "The foundational principle of Neoplatonic thought is the doctrine that to be is to be intelligible". Various arguments are available to ground this claim, but Perl focuses on the Parmenidean point that thought always involves the apprehension of a being of some sort or other; correlatively, nothingness would be wholly unknowable, not something capable of being grasped by a mind. (What would the mind be grasping, exactly?) In other words, whenever we are thinking, we are necessarily thinking about something, some being or other (or "being" in general). This observation is supposed to establish the fact that there is at least an intimate connection between being and intelligibility. Relatedly, thought cannot overstep the bounds of being (the mind cannot think about the unknowable or unintelligible), and being cannot overstep the bounds of thought. Perl $(2007$, p. 6) observes: "It would be incoherent even to postulate an unintelligible being, a being that cannot be thought, for to do so would already be to think such a being." The best (only?) explanation for these tight interconnections is not that being and intelligibility are distinct yet overlap by coincidence, nor that some additional explanatory factor draws them together (what could that factor be, if not a being?); rather, these tight interconnections between being and intelligibility are best explained (or, perhaps, can only be explained) by positing their strict identity, an identity both in sense and reference. To be real is to be knowable by a mind, and to be knowable by a mind is to be real.

Given this identification of being with intelligibility, a second proposition readily follows, namely, Plato's claim that the Forms (abstract universals like "humanity" or "mammal" or "Justice") are real. According to Plato, what the human intellect grasps are universals, not particular material objects. The latter are apprehended in a nonintellectual manner by sense perception, and so, they are the subjects of opinion rather than knowledge. Forms are intelligible, so they must be 
real. ${ }^{6}$ By extension, a third proposition obtains, namely, that material particulars are not real—strictly speaking, they are appearances/manifestations/reflections of beings, not beings themselves. They are not nothing, but they are not real, either.

When faced with that last, seemingly paradoxical, claim, it may be helpful to recall the Platonic mirror analogy: there is a real apple sitting in front of the mirror (which real apple is the analogue of a Form); while the apple's reflection in the mirror's glass, its appearance or manifestation, is, in a sense, not real-it is just a reflection of something really real. The apple's reflected image in the mirror is not absolutely nothing, but it cannot be considered a being in quite the same way as the actual apple sitting in front of the mirror. For Plato (and for Neoplatonism), the same goes for material particulars in relation to Forms. There is thus a sort of middle ground between being and nothingness: namely, the appearance/manifestation/reflection of being. Perl writes (Perl 2007, p. 7): “As appearances or images, sensibles are not mere illusion, or nothing (as Parmenides may have believed), but neither are they being itself, the reality which appears, the universal natures apprehended by the intellect." Individual material objects and their individual traits are merely reflections of Forms, such that they can be sensed but not literally known —what the mind grasps about a particular apple is not its unique particularity but, rather, what is common to apples generally, like the Form "apple" or appleness. As he puts it later on (Perl 2007, p. 83): “Forms are real beings precisely in that they are what is perfectly intelligible; sensibles are less than really real in that they exhibit intelligible natures which they themselves are not, and hence are not beings but multiple, differentiated appearances of unitary forms."

I wish to hold off on assessing Perl's Neoplatonism until the next section, and I do not intend to delve in any detail just now into the various objections that might be made to these first three Neoplatonic commitments. But cognizant of the fact that many readers (especially those steeped in contemporary analytic metaphysics) may already have formed grave reservations, a couple of brief observations are probably in order. Regarding the status of appearance/manifestation/reflection with respect to being and nothingness: this Neoplatonic model might initially seem counter-intuitive to readers today, because in some contexts, we tend to use "being" and "nothingness" as contradictories, admitting no intermediaries. We often assume that something either exists or it does not. Along these lines, some important metaphysicians both historically (most famously John Duns Scotus ${ }^{7}$ ) and still today would affirm that "being", properly construed, is equivalent conceptually to "not nothing". On that view, whatever is not absolute nothingness is ipso facto something and, thus, a being of some sort or other. That is certainly a prima facie plausible stance, a point Perl himself concedes (Perl 2014, pp. 34-35). Yet, in his defense, there are other ordinary language contexts where we contrast being not with absolute nothingness but with other sorts of items; we have already seen the contrast between being versus appearance (which Perl goes on to develop further in his own reply to this concern (Perl 2014, pp. 35-38)), but we might also choose to contrast being not with nothingness but, instead, with possibility (i.e., contrasting an actual state of affairs with a merely possible, nonactual state of affairs), where a specified possibility seems distinct from absolute nothingness insofar as it too displays intelligible content we can think and talk about (e.g., we can think and talk intelligibly about gryphons and their various properties while recognizing that they are merely possible, nonactual entities). In still other contexts, we might contrast beings with fictions (Christian Bale as contrasted with Batman), or we might contrast beings with past entities (at least for those who adhere to a presentist ontology of time, past events are no longer real, yet can still be intelligibly thought about), etc. If a nonactual possibility is viewed as distinct from absolute nothingness and, yet, is not viewed as a being, then one has seemingly opened up a conceptual space for intermediaries between being and nothingness.

6 See Perl (2014, pp. 22-27) for a review of additional Platonic arguments for the reality of Forms.

7 For a recent exposition of Scotus' accounts of being, essence, and existence, see Cross (2013); also helpful is Cross (2001), particularly regarding the theological import of Scotus' understanding of being. Perl $(2014$, p. 6) is not a fan of Scotus, to put it mildly. 
The desire to avoid just such an opening is, of course, one reason why some-like those in the aforementioned Scotist tradition-have granted possibilia the status of beings in the broadest possible sense of "beings" and, then, have gone on to distinguish between categories like merely possible beings versus actualized beings; it is also one reason why still others have gone on to make comparable moves using different terminologies, like the Meinongian divide between existent entities versus subsistent entities. My point is not that Perl's Neoplatonic understanding of being is superior to competing accounts of being (of which there are a good many in the recent analytic literature) ${ }^{8}$ but, rather, that it can legitimately be viewed as a competing account, neither obviously false nor clearly implausible.

A further potential concern that is worth mentioning at this stage: How it is that we are able to talk and think intelligibly about material particulars? Does not that ability undermine either the claim that being = intelligibility or the claim that such particulars are not really beings? In reply, the Neoplatonist might press the point that, when we talk about material particulars, we are usually talking about some categories or classes, i.e., things we can actually cash out in terms of universals. By contrast, when we actually have to refer very specifically to a particular qua particular, doing so successfully must involve, somewhere along the line, an act of brute material ostension (e.g., pointing at something). Think, for instance, of a shopper trying to tell a grocer which apple he wants to buy. If the row of apples is outwardly indistinguishable, such that he cannot pick one out by way of drawing attention to any distinguishing characteristics (i.e., by way of drawing attention to the manifestations of universals possessed by a certain apple that differ from those of the other apples on either side of it (such as green color rather than red or yellow or large size)), then eventually, the shopper will just have to point at that particular apple. Such ostension is not an intellectual act, strictly speaking. It is a physical one appropriate to physical things grasped via sense perception rather than intellection.

A fourth proposition is implicit in the preceding, and though not stressed by Perl, it is no less important: namely, MN is false. According to Neoplatonism, Forms are real; indeed, they are the really real, the paradigmatic true beings. Whatever is not a Form or an intellect is either nothing at all or a mere manifestation/appearance/reflection of a Form and, thus, a sort of diminished quasi-reality (like the reflection in a mirror) that must somehow be dependent on and derivative from the really real (just as the reflected image is dependent on the external object it is reflecting and would disappear if that object were moved from in front of the mirror). As Perl notes later (Perl 2007, p. 11), this tradition is quite clear on the existential priority of Forms over and against the material particulars that reflect them, “... for Platonic thought, whenever different things share (or 'participate in') a common attribute, that attribute itself, as the one nature by which all the participants are such as they are, is ontologically prior to the participants". Or, as he puts it later (Perl 2007, p. 20), "The instances depend on the form to be such as they are, while the form, as a unitary intelligible nature capable of appearing in many instances, is independent of them. The instances, so to speak, owe everything to the form, as that by which they are what they are, while the form, as the nature which, by appearing in them, makes them what they are, owes nothing to the instances." Such an ontology is clearly incompatible with MN on multiple fronts. Most basically, it cannot be the case that the only sort of irreducible reality is physical reality, because the Forms are irreducibly real, and they are not physical. In fact, it would be difficult to imagine an ontology more inherently, categorically (in several senses of "categorically") opposed to MN than the sort of Neoplatonism laid out by Perl, according to which, not only are there real things that are not material, but material things are not really real at all—at best, they are manifestations of beings, secondary to and dependent on transcendent nonmaterial realities. ${ }^{9}$

8 See for instance Berto (2012), (McDaniel 2010a, 2010b, 2013a, 2013b), McGinn (2001, chp. 2), Merricks (2019), Moore (2015), Moreland and Craig (2017, chp. 9), Pruss (2011), Rami (2014), Textor (2017), Vallicella (2014), van Inwagen (2014, chps. 3 and 4). Neo-Scholastics have also made interesting contributions connecting up with the analytic debates on being-see for instance (Kerr 2015), Long (2005), (Miller 1992, 1996, 2002), and Nevitt (2018).

9 One might even suggest that proposition \#1 by itself entails the falsity of MN, for who could claim that at the most fundamental, irreducible level all reality is purely material (and hence, not in any way mental), while acknowledging, at the same time, that reference to the mental (intelligibility) is bound up in the very definition of "being"? I think Perl recognizes 
A fifth proposition: The realm of the Forms is complex and involves not just identity but difference. The Form "mammal" is not the Form "vegetable", yet both are fully real. By implication, then, the realm of being incorporates distinction, difference, and multiplicity, in contrast to Parmenidean monism. ${ }^{10}$ This recognition of irreducibly real differentiation also allows for the recognition of hierarchies of generality and dependence among the Forms themselves, as Perl (2007, p. 7) notes: "Difference, no less than identity, is necessary for and constitutive of being. But this doctrine of being as an internally differentiated multiplicity of forms is itself a consequence of the intelligibility of being. As Plato points out, the forms are intelligible only in relation to each other, by the method of 'collection and division,' whereby the less universal forms are identified as differentiated specifications of the more universal, and the more universal forms are understood as unities overarching and pervading a multiplicity of less universal ones ... " In other words, more specific Forms like "apple" are differentiations of more generic Forms (like "fruit" and "edible" and "substance"), and those more generic Forms possess an overarching unity that allows them to retain their own distinctive identity while also permeating the specific Forms that fall under them. Plato's Forms thus exhibit among themselves a necessary structural order of interrelationships and hierarchies. Perl stresses this again a bit later (Perl 2007, p. 10): "In the absence of differentiation, distinction, and determination, and hence in the absence of multiplicity, there is no intelligibility and hence no being. The doctrine that being is constituted by determination or differentiation, and that it is therefore necessarily multiple, is a direct consequence of the principle that to be is to be intelligible." These points also imply that, just as material particulars depend ontologically on the Forms they manifest, so there are dependence relations amongst the Forms themselves, with the more specific being ontologically posterior to the more generic. "Triangle" and "square" are real Forms, but their reality depends, in part, on their sharing in the higher-level Form "shape", which itself depends on still other higher-level Forms, further and further up an ordered hierarchy organized partly on the basis of generality/universality. Finally, the fact that each and every Form is distinguishable from other Forms entails that each and every Form is finite; they all have ontological boundaries, so to speak, that hive one form off from another. The defining characteristics of "apple" entail its distinction from Forms both lower down and further up the hierarchy and, also, constitute it as finite.

If Neoplatonism involves the acceptance of multiple fundamental distinctions-between being versus nothingness versus appearance, plus innumerable distinctions within the realm of being/Forms and, correspondingly, among their appearances-a crucial sixth proposition commits to a kind of simultaneous grounding plus transcendence of these distinctions by what Plato calls the Good. Perl writes (Perl 2007, p. 8) that, for Plato, "goodness is the principle of intellectual understanding and of intelligibility itself. The intellect by nature demands to see goodness in its object in order to understand, to make sense of it. Any thing, event, action, or process can be intellectually understood only in terms of the good which is the ultimate 'why' for it ... [T] he Good provides that which makes the forms able to be known and the intellect able to know them." That last sentence might initially seem to contradict the prior commitment to the identity of being and intelligibility, making it appear instead as if the Good were an explanatory factor mediating between and linking up two distinct items (being and intelligibility). But I take it that what Perl actually means is something like the following: necessarily, every being can be rightly understood teleologically, as something having an inherent, objectively valuable purpose or end. That inherent, objectively valuable purpose or end is not unrelated to that being's status as knowable. Beings are knowable because they are good; this goodness is

this when he writes (Perl 2014, p. 8): "In this tradition being is neither 'mind-dependent,' in the sense of being produced by or posterior to mind, nor 'mind-independent,' in the sense of existing apart from or without mind ... Since to be is to be intelligible and to think is to apprehend being, thought and being can be considered only in their togetherness: neither can be separated from or reduced to the other.".

10 For a concise summary of the original reasoning behind Parmenidean monism, and for some of the Platonic objections against it, see Perl (2014, pp. 15-17). 
not some third ontological posit that must be added to being but, rather, is inherent to it- "being" understood from a different point of view, as it were. Perl (2007, p. 35) adds: "To be intelligible, then, is to be good, and the intelligible determination or form in each thing, by which that thing is what it is, is that thing's way of being good." 11

Perl acknowledges that the ontological status of the Good is somewhat unclear in Plato's own writings, since in the Platonic dialogues it is spoken of both as a Form itself and also as a principle transcending the other Forms, in some sense prior to and productive of them. One of the tasks of later philosophers in this line of tradition would be to clarify the nature of the Good and its precise status in relation to the Forms (and their material reflections), and we will come back to this issue presently.

So far, the central commitments of Neoplatonism can be grounded pretty explicitly in Plato's original works, and Perl provides a number of citations from the Platonic dialogues to support his exegesis. However, he acknowledges that a seventh proposition may be only implicit in Plato (implicit partly via his use of "Form" and "Idea" seemingly interchangeably) and that a full articulation of it is brought out explicitly by the first philosopher actually accorded the title "Neoplatonist" historically, namely, Plotinus (205-270AD). On Plotinus' account, the Forms are also literally ideas, the necessarily existent multitudinous thought-contents of an eternal and necessarily existent super-Mind (Intellect itself), which eternally thinks them and knows them in thinking them. This identification of Forms with literal ideas, actual mental contents, serves to safeguard still further that first, key Neoplatonic commitment to the identification of being and intelligibility, for, as Perl explains (Perl 2007, p. 9), "if being were external to thought, then the actual content of thought, what thought apprehends, would not be reality itself but some image or impression of it. Thought, therefore, on this view, could never reach reality ... Rather, as Plotinus argues ... intellection, in that what it apprehends is pure idea, contains its object in itself ... Conversely, being, as form or idea, can be nothing but the content of thought... " By implication, when we as human beings come to know a Form, our limited finite minds are in that very act getting plugged into the Super-mind, Intellect itself, literally sharing in its eternal thought. Insofar as Plotinus conceives of Intellect ("Nous" in the Greek) as a god, a further implication is that human knowledge is also, in a sense, divine knowledge: in knowing any Form, no matter how lowly, we know at least a small part of the contents of a divine Mind. Plotinus also sees Intellect as, in some sense, one with Being, insofar as the entire multitudinous realm of Forms (the whole of being taken together, being with a capital " $\mathrm{B}$ ") functions as the content of its eternal act of intellection.

The reader may, at this point, wonder: doesn't this seventh commitment rule out Neoplatonism, and, by extension, theophanism, as an option for agnostics? Not necessarily; observant pagan polytheist that he was, Plotinus naturally thought of Nous as one of the gods, but it need not be thought of in that way, as divine; Plotinus' Nous is certainly very far from being readily identifiable with the God of JCT, lacking as it does some of the essential attributes of the God of JCT, like omnipotence. Moreover, on Perl's reading of Plotinus, Intellect seems not to be a personal entity, let alone a conscious mind in the way we think of conscious minds (namely, as substances engaged in distinct acts of thinking via a distinct faculty of thought). This becomes more evident in his later, more expanded treatment of Plotinus' understanding of the precise relationship between Intellect, being, and consciousness (Perl 2007, pp. 84-86) and in his treatment of a related point in Proclus' ontology (Perl 2007, pp. 66-67). Those details can be left aside for our purposes. Still, this seventh commitment does serve to reinforce and further justify the fourth proposition, i.e., the falsity of MN. Plotinus' Intellect may or may not be viewed as divine, but it is certainly not a physical entity or reducible to physical entities.

11 Some readers will be asking, at this point, if all beings are good simply insofar as they are beings, what place is there within Dionysian Neoplatonism for a proper recognition of evil? Perl supplies an extended treatment of this very issue (Perl 2007, pp. 53-64), and see also his (Perl 1994b, pp. 331-34). However, this is not essential for our limited purposes, so I will not attempt to summarize it here. 
An eighth proposition can be seen as a clarification and development of the second and fifth propositions taken together. Recall the aforementioned claim that Forms come in an inherently ordered hierarchy fixed in large part by generality, with more generic/universal Forms being higher up and ontologically prior to the less generic. That commitment raises the question: Could there be something like a most generic Form, some attribute that all Forms whatever share in or participate? In other words, if "dog" and "cat" share in "mammal" and "mammal" and "reptile" share in "animal" and "animal" and "mineral" share in "substance", as we go further and further up, do we reach an endpoint to the hierarchy, something akin to a single Ultimate Form that all lower-level Forms share? Relatedly, one might ask whether there could be something that not only the Forms but also their containing Intellect share in, and not only the Forms and Intellect but also material particulars (if derivatively). ${ }^{12}$ Plotinus' answer is a qualified affirmative: yes, there is something that they all share in, for they all have unity in common. Everything that in any way exists (or, in the case of a material particulars, reflects existence or quasi-exists) is, in some way, one, such that unity is the crucial precondition of being. For example, Fido the dog only exists because there is a coherent unity of his material parts and properties, and the Form "dog" only exists because all its associated Forms are appropriately unified, etc. Or, as Perl (2007, p. 10) puts it:

Again, every being must have unity, must be some one being, in order to be; but being as a whole and each being within it involves multiplicity of content, without which it would not be intelligible. Therefore, each being can be only in virtue of the unity by which it is this one being ... In short, for any being, to be is to be finite and unitary, and hence to be dependent on the unifying definition by which it is the one being that it is. Having discovered that being as such must be dependent, Plotinus therefore turns to the One as the ground or source on which being depends, that by which all beings are beings.

Later on, he writes of this again (Perl 2007, p. 22): “Just as all fires are fires by having, or participating in, the intelligible form Fire, so, since anything can be only by being one, all beings are beings by having, or participating in, the One." Properly understood, unity also inherently involves difference and differentiation. Fido is one thing not just in the sense that its parts and properties intelligibly cohere but, also, in the sense that Fido is separate from other dogs and other beings. To be one is to be internally coherent and distinct from others, to be undivided oneself but divided from others. In grounding the unity of each Form and each appearance of Form (i.e., each material object), the One thereby also grounds the differences and distinctions within and among them.

As the precondition and source of being, unity or the One can also be considered valuable, in fact, as goodness itself. (For what could be better than that on which all reality and, so, all lesser goodness, depends?) The Good can thus be identified with the One, giving us a key ninth proposition. Another reason for making this equation is provided by Perl $(2007$, p. 36) when he notes that "the unity of any thing, that very integration of all its contents into one whole, is what renders the thing good, successful at being what it is. Unity and goodness in a being are the same ... The Good, then, is the same as the One, as the universal formative principle by which all beings are beings." Similarly, using life as a concrete example, he writes (Perl 2014, p. 57) that "it is the integration of many elements, tissues, and members into a single living organism that make something a tree, or a dog, rather than

12 The "derivatively" here ultimately requires a good bit of nuancing, the details of which are interesting but must be left aside here. For those details, see Perl (2007, pp. 75-81), and, also, his (Perl 1994b, pp. 344-51) and (Perl 2014, pp. 131-32). Elsewhere, he provides a less technical, vivid illustration of the basic idea (Perl 2013, p. 31): "We can thus imagine the whole of reality as a series of vessels, each of which can be filled from above only in ceaselessly emptying itself into those below, and God as the overflowing love that runs through and fills them all." See also Perl (1994a, p. 20) for an earlier use of the same image. In Perl's view, then, the reality of hierarchy and the derivation of one level of being (or quasi-being) from another (especially material particulars from Forms) is still compatible with a kind of immediate dependence of all upon the One. 
an incoherent jumble of unconnected stuffs. This integration is its good, as what enables it to function and thus to be itself, the one identifiable thing that it is, at all."

That ninth commitment to the claim that the Good = the One can be seen as clarifying Plato's own somewhat ambiguous notion of the Good. In Plato, it was arguably unclear whether the Good was itself a Form or transcended Form altogether (though Perl (2014, pp. 58-60, 115) notes that there is substantial textual evidence for the latter view in Plato); Plotinus, however, is quite clear that the Good is not a Form. The Good/One is at the "top" of the hierarchy of generality, not in the sense of being the most general Form among Forms (hence, my stating above that Plotinus' affirmative answer on that issue was a qualified one), but in the sense of not belonging to the hierarchy at all; the Good/One transcends beings-it is not a being itself. Why? Because, as we have seen already, beings are necessarily determinate, finite, and limited; part of what characterizes them as intelligible is the fact that they can be distinguished one from another, and that can only be done because they are determinate, finite, and complex entities. They have ontological borders. The Good/One, by contrast, is infinite. Absolutely everything participates in it and depends upon it, ${ }^{13}$ such that it cannot rightly be thought of as having boundaries or limitations. The super-generality of the Good/One renders it beyond the hierarchy of beings altogether and rules it out from being properly considered as a being on its own account. Elsewhere, Perl (2014, p. 157) puts this as follows: "Plotinus argues from the recognition that any being is a being in virtue of its unifying integration, and so is not just integration itself, to integration itself, or the One, which is not the distinct integration of any being, as the universal principle of all beings as such." Fido exists because his parts and properties are coherently and intelligibly (and, by implication, rightly) integrated-Fido manifests or participates in unity (i.e., the One/Good). Much the same can be said of the Form "dog", which exists because of the coherent integration of its own associated Forms. But Unity, the Good/One, is not itself a being, a thing-to-be-integrated; it is present to beings as that-which-unifies but is not itself a Form or distinct being on its own accord. If it were, then it too would have to be an intelligible, internally complex entity whose multiple parts or properties would stand in need of integration, and we would be faced with a vicious infinite regress. Perl writes (Perl 2014, p. 117) that, for Plotinus, "since to be is to be one, determinate, and therefore dependent, the One, as the enabling condition for beings, cannot be another being, one of the beings."

An implication of the preceding commitment provides us a tenth proposition: since to be is to be intelligible, the Good/One is not intelligible; neither the human mind nor even Intellect itself (the super-Mind) can grasp it, since it ("it") is infinite. It is not a being among beings but, rather,

13 I would tend to think that the manner or mode or type of participation must somehow be different in this case; in other words, what it is for a material particular to participate in a Form (e.g., Fido participating in "dog" - in other words, counting as a manifestation or appearance of that Form (for the equation of manifestation and participation, see (Perl 2007, p. 20))), and what it is for one Form to participate in another Form ("dog" participating in "mammal"), and what it is for all of these to participate in Intellect presumably differs from how all these participate in the Good/One, since the latter is not a being. Plotinus (and Perl) may use the same term, "participation", to describe the relationships involved in each case, but one might assume that, at least in the case of the connection to the Good/One, the term is being employed analogously rather than univocally. Or, perhaps not; maybe "participation" is just an extremely generic relationship applying identically both between beings and between beings and that which is beyond being. I am inclined to think that Perl actually holds to this latter view, but I am not quite sure. (In fact, one of the referees for this paper suggests that I am correct to flag this issue in Perl's work, adding that $\mathrm{s} /$ he considers it quite important for the interpretation of Plotinus' system. Since I am not a Neoplatonism scholar, I feel unable to adjudicate this interpretive question myself; yet, it does seem of some significance. So, I will simply quote here part of what the referee has stated in his/her report: "In fact it is quite impossible that beings acquire their unity (and hence being) by participating in the One in the same way that sensible particulars participate in the Forms. The reason is that the One is itself 'neither one nor many', so one can hardly appeal to its unity to explain the unity of beings. One has to instead envision it as a kind of active principle that somehow, in a quasi-deliberate fashion, produces the plurality of beings. This is, of course, what Plotinus did through his theory of emanation. That theory can be criticized on various grounds, but it is at least an attempt to address the question of how the One explains the existence of a plurality of beings. I fear that Perl's use of the term 'participation' for the relationship of the One to beings is a way of evading the need to give such an account. No doubt he does not want to attribute even quasi-deliberate action to the One, since that would make it too much like the God of traditional theism. (Note that his attitude in this regard is quite different from that of Plotinus, especially in Enneads VI.8.) At any rate, his ambiguous use of the term 'participation' should be flagged as a serious issue." 
the precondition for being, the principle of all beings, and thus, not itself a being at all. Yet, it is also not nothing (in the sense of absolute nothingness) - it transcends the very categories of being and nothingness, viewed as contraries of one another (and thus, as distinguished from each other as finite categories). We cannot speak or think intelligibly about the intrinsic nature of the Good/One; we can know that, in some sense, there must be ("be") such a thing ("thing"), but finite concepts and language are inadequate to think about and describe it. We can know what it is not (it is not finite, not dependent, not material, etc.) but not what it is. We cannot rightly even say that it is, in and of itself, literally "one" or "simple", if we take unity or simplicity in a sense corresponding to our finite concepts of them. The One is given that name or title by Plotinus, because it functions as the source of unity and, hence, of being for all beings and quasi-beings (Intellect plus Forms plus material particulars) and because that title serves to deny the multiplicity of it ("it"). But, from Plotinus' perspective, that reveals to us nothing about its intrinsic nature (and, of course, our normal concept of "intrinsic nature" cannot literally apply to it either, being a finite concept). Perl (2007, p. 11) writes: "In short, no common term whatsoever, including 'being,' can embrace both the One and its products, for the One would then be included within the totality and differentiated from others within it. Plotinus thus interprets 'beyond being' in a purely negative sense, as meaning, only, that the One is not any being." Strictly speaking, we would be better off putting even that title (the Good/One) to one side and simply leaving this principle nameless. In the face of this unknowable principle, silence seems the most appropriate course.

Plotinus' account of the Good/One thus also gives the Western philosophical tradition a foundation for so-called "negative theology" or "apophatic theology" (whereby the divine is conceptualized by denying predicates of it ("it"), rather than affirming predicates of it), assuming it makes sense to consider the Good/One as divine. Plotinus himself certainly did, giving us an eleventh proposition, namely, that the title "God" is appropriate to the Good/One insofar as it functions as the source of all things, and God is traditionally viewed as a Creator or causal source of beings. Still, for the present purposes, I would stress that it is not clear that we have to; in particular, it is not clear that the modern agnostic reader has to, and certainly Plotinus' Good/One (as interpreted by Perl) seems readily and radically distinguishable from the God of JCT. Among other things, it is not at all obvious that this Neoplatonic Good/One could be a personal entity or possess many (any?) of the traits typically associated with the God of JCT.

Plotinus' claim that the Good/One/God is unknowable (beyond being and, hence, beyond intelligibility) raises the further question of whether there is any hope for humans to gain some sort of access to it ("it") - if not cognitively, then, perhaps, in some other fashion. For Plotinus himself, the answer was yes; humans could achieve a kind of unity with the Good/One/God by way of progressing beyond intellection via the cultivation of meta-noetic mystical experience. (For Perl's nuanced explanation of this, see his (Perl 2007, pp. 93-97, 107-8).) Subsequent pagan Neoplatonists would devote a great deal of attention to the attempt to explore further this very issue, leading to some significant internal disputes about the efficacy of mysticism versus ceremonial magic; Jewish and Christian Neoplatonists would develop their own distinctive views on this.

Among those Christian Neoplatonists would be Dionysius. Despite occasional reformulations of Neoplatonic positions in order to bring them, at least outwardly, in-line with Christian orthodoxy, according to Perl Dionysius' worldview remains fundamentally in-step with that of Plotinus and Plato, such that a clear and continuous line can be drawn from their systems up through Dionysian Neoplatonism. That continuity crucially includes Dionysius' acceptance of the claim that the Good $=$ One $=$ God and the apophatic theology attendant upon this commitment. Perl (2007, p. 13) writes: "Dionysius expressly adopts the Parmenidean and Platonic account of being and thought as coterminous, and therefore locates God beyond both ... Dionysius' God, like the One of Plotinus, is transcendent, not in a vague, unspecified sense, but in the very precise metaphysical sense that he is not at all included within the whole of reality, of things that are, as any member of it. If he has no 'name,' this is because he is not anything at all ... If our thought cannot attain to God, this is not because of our weakness but because there is no 'there' there, no being, no thing that is God." If we thought of 
God as a being, we would thereby think of God as finite (since all beings are necessarily limited and determinate) and would thereby fail to think of God as God, as infinite. God is not a member of the ontological hierarchy but surpasses it altogether, even while grounding it. Elsewhere, Perl (2013, p. 24) puts this point as follows: "It is vital to recognize that God, for Dionysius, does not stand above the angels at the peak of this hierarchy as if he were merely the 'highest' being. God is 'beyond being' (hyperousios), that is, not any being, even the highest, because a being, for Dionysius, means something knowable, something comprehensible, something distinct, determinate, finite, and therefore something created. God, therefore, is not any member of the totality of beings, even the 'first' or 'highest,' but is rather the source or cause of that totality."

What does all that mean for Dionysian Neoplatonism's status as theistic, in the way that modern philosophers tend to think of theism? In another important passage, Perl seeks to clarify this (Perl 2007, p. 15):

We may be inclined to ask whether such a radical treatment of divine transcendence means that God simply disappears from view altogether, in such a way that, as has been remarked, 'the truth of negative theology is atheism.' But Dionysius' Neoplatonic negative theology transcends atheism no less than it does theism. To be sure, Dionysius is not a theist, since theism, as ordinarily understood, involves the claim that God exists (whatever qualifications may then be added concerning the 'mode' of his existence); and many misunderstandings have arisen from attempts to interpret Dionysius and other Neoplatonists theistically and thus not to take with full seriousness their insistence that the One or God is beyond being and is not anything at all, that no common term whatever can embrace both God and his products. But neither is Dionysius an atheist, for on his principles it is no more correct to say 'God is not' than to say 'God is' (i.e., is a being). Simply to deny that God exists, to say 'God is not' or 'There is no God' is still to consider God as some (putative) being, and then to deny that there is such a being, as when we say 'There is no tenth planet' or 'There are no unicorns.' This still treats God as some distinct conceptual object and so fails truly to intend God at all. Neoplatonic and Dionysian negative theology, on the other hand, refuses to consider God as anything at all, whether to affirm or to deny the existence of such a thing. Indeed, both 'theism' and 'atheism' are distinctively modern phenomena, which cannot properly be read into Neoplatonism.

This will surely be an unfamiliar sort of perspective to the eyes of most contemporary agnostics. The claim essentially is that the Dionysian Good/One/God is not the God of JCT, as that entity is typically understood by both theists and atheists-most especially, the Dionysian God is not an existing entity.

We can now articulate the crucial (for our purposes) twelfth proposition, namely, the commitment to theophanism: all beings are manifestations or appearances of the Good/One/God. From the Dionysian perspective, as articulated by Perl, although God is utterly transcendent, wholly beyond all beings and quasi-beings (and, by extension, beyond concepts and language), it is also the source of all beings and quasi-beings. They only exist because of their participation in God.

To better understand what is intended by that claim, consider again the use of "manifestation" and "appearance" language employed in the earlier propositions. Individual material particulars are not identical to Forms, but they do manifest or reflect the Forms. Since the Forms are abstract universals, they are never literally bounded by or restricted to any one particular spacetime location. Such spatiotemporal restrictions are characteristic of physical things rather than Forms. However, Forms are certainly manifested in spacetime, i.e., manifested by spatiotemporally located material particulars. Think back to the mirror analogy: the apple is not literally in the mirror, but its reflected image is. (Here, the analogy breaks down somewhat, because the apple sitting in front of the mirror obviously has a single specific spatiotemporal location of its own, whereas a Form does not. Though we can speak metaphorically of a "realm of Forms", Platonic Forms are, of course, not literally in some ghostly realm or Platonic heaven "up there".) Because its reflected image is in the mirror, we can say that 
the real apple appears in the mirror. In that sense, the real apple is, in fact, present in the mirror-not, of course, in the sense of being spatially constricted to some portion of glass, but present precisely via its image, which image draws all its content from the apple, its exemplar. In the Platonic dialogue the Timaeus, the analogue of the mirror is space. Whether or not we wish to take that literally (i.e., whether we actually think of space as a kind of receptacle for the manifestations of Forms), by thinking of it in this way we can get some sense of what the manifestation/appearance/participation relationship involves. Or, as Perl (2007, p. 20) puts it: “The individual character of a sensible thing, e.g., the beauty of Helen, is a differentiated appearance of the one form, in this case Beauty itself, and the form itself is in the instance in that it appears here, and, by so appearing, makes the instance what it is, e.g., beautiful." ${ }^{14}$ Now, what Dionysian Neoplatonism suggests is that something closely akin to that same relationship (or, perhaps, the very same relationship) ${ }^{15}$ obtains between God and all beings (and quasi-beings); they are all manifestations or appearances of God. All reality is thus an unfolding or unconcealing of the hidden, ineffable deity. However, there is a crucial point of difference: God does not exist as a separate entity or being outside of and independently from its manifestations in the way that a Form does exist independently of the material particulars that participate in it/reflect it (such that the Form "dog" would be still be just as real if Fido and all his fellows became extinct). Why? Because as we have already seen, God does not exist at all. God is beyond being. According to Perl, this transcendence should not be misconceived as constituting God as a sort of super-being (in the sense of His being just a special, higher sort of thing). He or It ("he" or "it") is not a distinct thing at all. God, thus, does not exist, in the sense of existing as a separate determinate being on its own account, and yet, there is still a sense in which it is present to things, namely, present to the beings and quasi-beings that participate in it/manifest it. That is the only legitimate sense in which we can say that God has a presence or "stands out" from nothingness (i.e., "exists" in the etymological sense of "exists"—a "standing out from"): divinity is manifested via Forms, material particulars, and Intellect, and God is thereby presented.

Perl (2007, p. 22) makes the point as follows: “If the One were merely 'other' or 'separate,' it would be another being, and so would be limited in relation to others. Precisely as transcendent, infinite, beyond being, it must be not separate but present to all beings. And precisely as present to all beings, it is not any one of them, and so is transcendent." So, it is not identical to any one of those things (whether Intellect or any Form or any material particular), nor is it identical to all of them considered as a unified collective (as a pantheist might maintain). Yet, it is truly manifested by all of them, both singly and collectively, and by virtue of that manifestation, can be said to be present. It is both immanent and transcendent, manifested in beings yet beyond beings. There is thus no conflict between transcendence and immanence, properly conceived. Perl (2007, p. 112) argues that "transcendence in no way implies

14 Also helpful on this issue is Perl (2014, pp. 28-31) treatment of the closely related Platonic distinction between copies versus images (a distinction not really captured by the mirror analogy). However, on the whole, I am not confident I have fully grasped Perl's thinking regarding the status of Forms vis a vis space and spatiotemporal location. Some of his further remarks (Perl 2007, pp. 21-24) regarding the transcendence versus immanence dialectic with respect to Forms and space, and his attempt at reconciling Plotinus' and Proclus' prima facie divergent approaches to this, seem problematic (if I have understood them correctly), since, at one point, Perl appears to be favoring a reduction of the "reality versus manifestation" distinction to a mere distinction between modes of human cognition (as if the distinction would not obtain were there no people possessed of both intellects and sense perception). This is reinforced by some of his other remarks on the relationship between cognition and being (Perl 2007, pp. 87-89; 2014, pp. 37-38), though those should perhaps be read in light of an earlier relevant discussion (Perl 1994a, pp. 25-26), which gives a greater impression of the objectivity of the distinction (i.e., its independence of the specifically human sense versus intellect divide). Or, perhaps, in Perl's view, the presence of humans possessed of dual sense and cognitive faculties is not a contingent matter of fact that could have been otherwise but, rather, a necessary feature of the world, a necessary part of the unfolding of the One. Such a claim would accord with his wider views concerning the absolute necessity of our world's unfolding from the One-see Perl (2007, pp. 49-52). In that case, my concern with this point would be defused or at least mitigated (though other, distinct concerns would then arise concerning the plausibility and theological orthodoxy of such a necessity-of-humanity hypothesis). At any rate, hopefully, what I have said in the main text above is a basically accurate (if incomplete) rendering of Perl's view of how Forms relate to their spatial instances, and it should suffice for our purposes.

15 I refer the reader again to my earlier footnote on the participation relationship in Perl's understanding of Neoplatonism. 
separation or duality between God and the world, which would leave the world itself godless and hence unworlded and thus lead to nihilism. Rather, the transcendent is precisely that which is given through, in, and as the world. The more transcendent God is, the more-not the less!-intimately present he is to the world; the absolutely transcendent God of Neoplatonism is therefore nothing but what is manifest in and as all things ... " And Perl (2007, p. 73) very much means all beings: "The entire hierarchy of reality, therefore, from the highest seraph to the least speck of dust, is the immediate presence and manifestation of God, of unity and goodness, according to the different modes and degrees that constitute the different levels of being." More poetically, he writes (Perl 2014, p. 168): "Wherever we turn our gaze, we are seeing God as it were in a mirror, for this is all there is to see, this is what all being is." Or, stated differently (Perl 1994b, p. 320), "it follows that the entire cosmos is a symbol of God ... to be is to be a symbol".

That is theophanism: the claim that, even though the Good/One/God is not a being, nor is it all beings, all beings are manifestations or appearances of the Good/One/God. Trying to predicate otherwise of God (assigning God literal attributes, for instance) would result in our misconceiving of it as a being and, thus, as finite. Any such conception must be inadequate, because God cannot be finite while also functioning as the needed ontological source of the unity (and, hence, existence) of each and every being and quasi-being.

Yet, that language must not be misread as implying that, because God appears in or as beings, there is something (something) distinct from the appearances, a reality lying behind them (as one can suppose is the case with Forms and their material manifestations). Perl writes (Perl 2007, p. 33): "When we speak of reality as the appearance of God, we must remember that since all reality is theophany, God, as 'that which appears,' is not another being, another member of reality. The doctrine of being as theophany means not that God is and is himself, and also appears, but rather that God is nothing but what is differently present, or appears, in and as all things." Once again, this is not pantheism, because God cannot be equated or identified with any of his appearances (or all of them), since they remain beings and God is not. God is that by which they are beings, but he is neither a being nor the totality of beings and, thus, cannot be equated with them. Faced with the worry that this effectively reduces God to his manifestations, Perl (2014, p. 172) replies: “This conclusion may seem like an excessively 'minimalist' reading of ... the entire Neoplatonic doctrine of the One beyond being, reducing God or the One to nothing but that fact that beings exist. But where else, indeed, should we fall prostrate in silenced adoration, if not at this very fact, which at once demands recognition and defies explanation? The question 'Why are there beings, rather than nothing?' cannot be answered, but must be understood as a way of expressing the necessarily unquenchable wonder that there are beings; and that is all that can properly be meant by positing the One or God as the first principle of beings as beings."

Moreover, this is not any sort of monism that would claim that what we think of as the world is a mere illusion, with God being all that is really real. Again, God is not real (is not a being), and an appearance is neither an illusion nor absolute nothingness. Perl writes (Perl 2007, p. 34): "To say that the world is the manifestation or appearance of God, then, is not to say that it is not real. Rather, Dionysius' Neoplatonic point is that reality itself is appearance: to be real means to be intelligible, to be given to thought, and thus to be appearance ... As Dionysius' Neoplatonic metaphysics is neither theism nor atheism, so also it is neither monism nor dualism, but can only be called, for want of a better term, 'theophanism'." Later on, Perl adds, even more provocatively (Perl 2007, p. 130), "Just as the God of Dionysius and the Neoplatonists transcends the opposition between theism and atheism, so he transcends that between monotheism and polytheism, for he is strictly speaking neither one nor many in any positive sense." 16

16 For more on the surpassing of the monotheism versus polytheism divide (as that is usually understood), see Perl (2010). 
So, Perl stresses the fact that theophanism, like the original pagan Neoplatonic affirmation of the Good/One, is neither atheistic nor theistic. In fact, for him, the label "theophanism" would ideally overtake and replace "theism", given the latter's inadequacy. As seen above, that inadequacy results from theism's historical and contemporary association with the claim "God exists"; from the perspective of Perl's understanding of Neoplatonism, that claim is simply false. Atheism is also false, since it is caught up in the same conceptual quagmire. The better way forward is to sidestep and surpass the atheism versus theism dialectic altogether by questioning the metaphysical assumptions it rests on: namely, a philosophically suspect account of being. Once that mistake is rooted out, theophanism can be seen as a better philosophical option.

Yet, can it be seen as an option for agnostics, specifically? It might seem as if it cannot, since theophanism involves the rejection both of atheism and of theism, as those views are typically formulated and understood. And one might suppose that any settled rejection of either theism or atheism (let alone both) would automatically place one outside the camp of agnosticism. In the next section, I will first seek to clarify this issue, assessing the workability of Perl's theophanisms from the standpoint of agnosticism. I will then provide some brief concluding remarks by way of assessing its philosophical plausibility more generally.

\section{Assessing Theophanism}

When it comes to assessing theophanism with a view specifically to its potential acceptability for agnostics, the most important point on which to settle is this: If the standard atheism versus theism dichotomy has been successfully overtaken and rendered moot on account of the improved understanding of divinity posited by theophanism, has agnosticism also been rendered moot, situated as it typically is within the context of that standard dichotomy?

I believe Perl would answer that, insofar as agnosticism is usually understood as interwoven with the atheism versus theism debate, the fact that that debate is predicated on a badly misconceived understanding of God as a being shows that agnosticism falls prey to the same misconception. The parties to the debate simply have not understood what they have been talking about; they have been wanting to talk about divinity, but they have been thinking of God as either existent or nonexistent, whereas, properly conceived, God cannot be either. If the agnostic has heretofore thought of herself as being party to a debate about a well-formed idea, "God", simply registering a well-founded lack of knowledge about whether or not that idea has a real referent, then seen now from the vantage point of Dionysian Neoplatonism, she can discern that her position was ill-considered. "Existent divinity" is something akin to a "square circle" and so is "nonexistent divinity". The proper attitude towards a square circle is not skepticism or suspension of belief but a recognition of its being an ill-formed concept. Once one has seen this, it becomes clear that the appropriate attitude to the debate between theism and atheism was never an affirmation of ignorance but, rather, an affirmation that the whole discussion ought not to have been taken up in the first place.

Surprisingly then, the attitude of an advocate of theophanism toward those who are party to the theism versus atheism debate (and, by extension, toward agnosticism) seems not unlike the attitude of the old logical positivists (though held for an entirely different set of reasons), namely, one of rejecting the very meaningfulness of the parties' language of "God", thereby rendering the whole enterprise moot.

At this point, it is worth highlighting that we have been speaking of agnosticism as typically understood and as defined in the Introduction of this paper. With that in mind, rather than seeing theophanism as entailing a rejection of agnosticism, one might instead take Perl's line of thought as indicating the need for a reformulation of agnosticism in broader terms. If one understood agnosticism as encompassing an epistemically well-founded suspension of belief about divinity of any and all putative kinds (whether supposedly existent or nonexistent or supra-existent or ineffably transcending all our conceptual categories), rather than just suspension of belief about the divinity of the God of JCT, then theophanism and agnosticism would be rendered incompatible for a different and, perhaps, 
better reason: namely, theophanism involves the affirmation of divinity (even if not the existence of a divinity), whereas agnosticism provisionally refuses it. Theophanism remains a form of NTNN, because it is not a version of theism (claiming as it does to surpass both the dialectic between atheism and theism and, also, that between JCT and alternative forms of theism), yet it does hold to the claim that all beings are manifestations of the divine. Thus, it still involves the incorporation of divinity (broadly construed) into its worldview, and my suspicion is that that too would be inadmissible in the eyes of a correspondingly broadened agnosticism.

So, whether we are using "agnosticism" in its typical sense or "agnosticism" in an atypical, much broader sense, either way, theophanism stands at odds with agnosticism. One might suggest that the former has at least rendered a service to the latter, helping it to discern a new justification for agnosticism's reformulation in more general terms (though the basic idea of broadening its scope beyond JCT is, of course, hardly new). I would be inclined to disagree, however. The suggested broader reformulation would, in one important respect, be disadvantageous to agnosticism, diminishing the probability of its truth by vastly widening the scope of its commitments. In other words, agnosticism would become a much more ambitious position were its original definition (as laid out in the Introduction above) bulked up with these bolded portions of text: at present, the most rational position for the normal inquirer to take regarding divinities is that she does not know (a) whether the God of JCT exists, does not know whether the God of pantheism (in its many versions) exists, does not know whether the God of panentheism (in its many versions) exists, and does not know whether any sort of divinity of any kind exists; does not know (b) whether the objective evidential probabilities point towards or away from any of those views; and does not know (c) whether the epistemic situation is liable to change much.

Such a broadening of agnosticism would render it tougher to defend, philosophically, and would also bring it closer in-line with generic religious skepticisms that are likewise problematic precisely because of their excessive breadth.

Theophanism should be rejected by agnostics, at least so long as they remain agnostics. That fact does not, of course, make theophanism false, and I would like to conclude by sketching a few brief evaluative remarks concerning the overall philosophical plausibility of Perl's theory.

While of considerable interest and worthy of much additional discussion (unfortunately, it has received almost none in the analytic philosophy of religion literature), ultimately, I do find theophanism problematic on several fronts. First, Perl takes it that being/intelligibility entails finitude. This is brought out explicitly in proposition \#5 and is also repeatedly stressed by him in maintaining that God cannot be supposed a being, because that would limit God and would be incompatible with the explanatory roles played by the Good/One/God within Dionysian Neoplatonism. The claim that being/intelligibility entails finitude is also closely connected to proposition \#10, according to which, the Good/One is unknowable-unintelligible precisely because not finite. This aspect of the system is very much open to question. Presumably, it is true that intelligibility to a finite human mind requires finitude (though, even that claim, taken without certain qualifications, might elicit puzzlement from my colleagues in the math department). But it does not seem impossible that an infinite Mind could encompass and grasp the infinite, and many philosophers within the JCT tradition would wish to affirm that omniscience is to be understood precisely in terms of the infinite knowledge of an infinite Being, namely God. So perhaps, it is the case that "being = intelligibility", without this entailing the further claim that to be intelligible is to be finite. Perhaps we can think of God both as knowable (if only to Himself) and as a nonfinite Being. This may call for some reassessment of how best to understand the notions of finitude and infinity in this context, but perhaps, that would be all to the good. ${ }^{17}$

17 A remark from Gunton (2002, pp. 85-86) concerning Scotus and the Cappadocians is relevant here: "Scotus ... arrived at a definition of infinity in terms of intensity, a conception closely linked to a trinitarian understanding of the relation of God to the world. God's infinity is to be found in the positive richness of his being, and not primarily in the absence of limit, whether spatial or temporal. (A similar point is made by Robert Jenson in conversation with Gregory of Nyssa. 
Perl is, of course, aware of that sort of objection, both as a standalone philosophical worry and as pointing to an alternative interpretation of the Neoplatonic tradition. For example, he notes (Perl 2007, p. 118) that some prominent Plotinus specialists (like Rist (1967, pp. 24-37) and Gerson (1994, p. 26)) read Plotinus very differently, as claiming that the One is an infinite Being. Perl disputes this exegesis (an issue on which I have no competence to judge) and upholds the plausibility both of equating being with intelligibility and of drawing out the finitude-of-all-beings claim as an entailment of that prior equation. It is that latter entailment that I am here questioning, and in my opinion, it does not receive adequate defense in Perl's works.

Second, there are also good grounds for questioning proposition \#1, the identification of being with intelligibility. As already noted, there are quite a few other options within the historical and contemporary metaphysics literature for how to think about the foundational nature of being, and while some of these alternatives certainly permit (or, at least, would claim to permit) the knowability of all beings, they would offer alternative grounds for that claim, i.e., grounds other than the simple equation of reality with intelligibility. As such, it is not obvious that alternative accounts necessarily fall victim to the destructive philosophical nihilism that Perl (2007, pp. 111-12) sees as resulting from the denial of that equation. Or, at least, the allegation that they all must succumb to nihilism, including even those accounts of being that are integral to larger theistic philosophical systems (such as the Scotism much-maligned by Perl), surely requires further supporting argument.

Third, there is a (perhaps inescapable) tension evident in Perl's persistent maintenance of the absolute unintelligibility of the One/Good/God on the one hand and, on the other hand, the multiple, seemingly quite intelligible explanatory roles assigned the One/Good/God in his philosophical system. In other words, this transcendent nonreality fulfills vitally important functions in this ontology, and one wonders whether a certain sort of intelligibility must inevitably "sneak in via the back door", so to speak. After all, part of how we form concepts or definitions of things (even incomplete concepts or definitions) is by way of identifying unique functional roles. Still, this may be as much a problem for Neoplatonism generally (or, indeed, any thoroughgoing negative theology) as it is for Perl's account specifically.

Fourth, there are other readings of Dionysian Neoplatonism on offer in the literature that cast doubt on Perl's employment of propositions \#8, 9, and 11 (i.e., the claims that "being/intelligibility depends on the One", that "the One $=$ the Good", and that "the One = the Good = God"). Suppose it is philosophically plausible to grant the Platonic claim that the unity displayed by finite beings is a manifestation of a distinct higher principle, namely Unity or the One. Suppose too that there are solid reasons for thinking that this principle is itself no ordinary Platonic Form but something belonging to a different category (bracketing for a moment Perl's own view that it transcends all our categories). Grant as well that the One bears some tight connections with the Good. Even admitting all that, it is not clear that the One need be seen as wholly identical with the Good (they certainly seem to differ at least somewhat in meaning), nor is it clear that either must be wholly identical with the divine essence. There are various alternative ways of taking a broadly Neoplatonic ontology at these points; importantly, there is the Palamite interpretation of Dionysius, according to which these high-level principles (the One and the Good) are best seen as uncreated divine energies, irreducibly real and inseparable, yet still objectively distinct both from one another and from the tri-personal Godhead that is their eternal source. This is, in fact, the more common way that Dionysius has been read and received within the Eastern Orthodox theological tradition, extending from Maximus the Confessor in the seventh century up through Gregory Palamas in the fourteenth. It is a reading still defended (both as a plausible interpretation of the Dionysian corpus and as an independently plausible bit of metaphysics) by Orthodox thinkers, such as Bradshaw (2004), Golitzin (2013), Jones (2005) and

'In Aristotle's understanding, something would be infinite because it lacked all boundaries; Gregory's God is infinite because he overcomes all boundaries.')." The reference is to Jenson (1997, p. 216). 
Lossky (1957). This alternative way of engaging with Dionysius allows for an ontology that still does much of the same explanatory work accomplished within Perl's system but without having to give up some of the core commitments of JCT (including the claim that God is personal).

Perl might respond to this third point by claiming that, although Dionysian Neoplatonism qua philosophy leaves no room for a personal God (let alone a trinitarian God), there is no strict incompatibility between Dionysian Neoplatonism and JCT qua theology. He seems to suggest this in his (Perl 2007, p. 122), and in his early work (especially his (Perl 1994b)) he placed considerable stress on the fit between his reading of Dionysius and Eastern Orthodox theology. However, this emphasis seems to have faded from his more recent work, and I do not see any way to render Perl's interpretation of Dionysian Neoplatonism (and, with it, theophanism) compatible with JCT, whether as philosophy or as theology. Others have raised this concern regarding Perl's system (e.g., Rhodes (2012)), and while it will not be a worry for non-Christian audiences (certainly, it will not be a worry for agnostics), it is likely to remain a sticking point for Eastern Orthodox readers like myself.

Much more could be said, but in the interests of space, I will leave that as my concluding evaluative point. I am sure Perl and other advocates of his theophanism will have responses available, and I look forward to any ensuing discussion of his interesting and unjustly neglected theory.

Funding: This research received no external funding.

Acknowledgments: I would like to express my sincere thanks to Francis Jonbäck for the kind invitation to contribute to this special issue of Religions and to the three anonymous referees for their many helpful comments.

Conflicts of Interest: The author declares no conflict of interest.

\section{References}

Berto, Francesco. 2012. 'To Be is to Have Causal Powers': Existence and Nature in Analytic Metaphysics. In Existence and Nature: New Perspectives. Edited by Matteo Plebani and Matteo Camposampiero. Berlin: De Gruyter, pp. 33-63.

Bradshaw, David. 2004. Aristotle East and West: Metaphysics and the Division of Christendom. Cambridge: Cambridge University Press.

Buckareff, Andrei, and Yujin Nagasawa, eds. 2016. Alternative Concepts of God: Essays on the Metaphysics of the Divine. Oxford: Oxford University Press.

Burns, Elizabeth. 2019. How to Prove the Existence of God: An Argument for Conjoined Panentheism. International Journal for Philosophy of Religion 85: 5-21. [CrossRef]

Bushman, Richard. 2008. Mormonism: A Very Short Introduction. Oxford: Oxford University Press.

Clayton, Philip. 2004. Panentheism in Metaphysical and Scientific Perspective. In Whom We Liv and Move and Have Our Being: Panentheistic Reflections on God's Presence in a Scientific World. Edited by Philip Clayton and Arthur Peacocke. Grand Rapids: Eerdmans, pp. 73-91.

Cooper, John W. 2006. Panentheism: The Other God of the Philosophers—From Plato to the Present. Grand Rapids: Baker Academic.

Crisp, Oliver. 2019. Against Mereological Panentheism. European Journal for Philosophy of Religion 11: 23-41. [CrossRef]

Cross, Richard. 2001. ‘Where Angels Fear to Tread': Duns Scotus and Radical Orthodoxy. Antonianum 76: 7-41.

Cross, Richard. 2013. Duns Scotus on Essence and Existence. In Oxford Studies in Medieval Philosophy. Edited by Robert Pasnau. Oxford: Oxford University Press, vol. I, pp. 172-203.

Dumsday, Travis. 2019a. Alexander of Hales on Panentheism. Sophia 58: 597-612. [CrossRef]

Dumsday, Travis. 2019b. Breathing New Life Into the World-Soul? Revisiting an Old Doctrine Through the Lens of Current Debates on Special Divine Action. Modern Theology 35: 301-22. [CrossRef]

Elliott, James. 2017. The Power of Humility in Sceptical Religion: Why Ietsism is Preferable to J. Schellenberg's Ultimism. Religious Studies: An International Journal for the Philosophy of Religion 53: 97-116. [CrossRef]

Gerson, Lloyd. 1994. Plotinus. New York: Routledge.

Givens, Terryl. 2014. Wrestling the Angel: The Foundations of Mormon Thought_Cosmos, God, Humanity. Oxford: Oxford University Press. 
Gocke, Benedikt Paul. 2013. Panentheism and Classical Theism. Sophia 52: 61-75. [CrossRef]

Goff, Philip, William Seager, and Sean Allen-Hermanson. 2017. Panpsychism. In The Stanford Encyclopedia of Philosophy, 2017 ed. Edited by Edward N. Zalta. Available online: https://plato.stanford.edu/archives/win2017 (accessed on 20 April 2020).

Goff, Philip. 2019. Galileo's Error: Foundations for a New Science of Consciousness. New York: Pantheon.

Golitzin, Alexander. 2013. Mystagogy: A Monastic Reading of Dionysius Areopagita. Collegeville: Liturgical Press/Cistercian Publications.

Gunton, Colin. 2002. Act E Being: Towards a Theology of the Divine Attributes. Grand Rapids: Eerdmans.

Jantzen, Grace. 1984. God's World, God's Body. Philadelphia: The Westminster Press.

Jenson, Robert. 1997. Systematic Theology Volume I: The Triune God. Oxford: Oxford University Press.

Jones, John D. 2005. An Absolutely Simple God? Frameworks for Reading Pseudo-Dionysius Areopagite. Thomist 69: 371-406. [CrossRef]

Kerr, Gaven. 2015. Thomist Esse and Analytical Philosophy. International Philosophical Quarterly 55: $25-48$. [CrossRef]

Lataster, Raphael. 2014. The Attractiveness of Panentheism—A Reply to Benedikt Paul Gocke. Sophia 53: 389-95. [CrossRef]

Lataster, Raphael. 2015. Theists Misrepresenting Panentheism-Another Reply to Benedikt Paul Gocke. Sophia 54: 93-98. [CrossRef]

Levine, Michael. 1994. Pantheism: A Non-Theistic Conception of Deity. London: Routledge.

Levine, Michael. 2007. Pantheism. In The Stanford Encyclopedia of Philosophy, 2007 ed. Edited by Edward N. Zalta. Available online: http://plato.stanford.edu/entries/pantheism (accessed on 20 April 2020).

Long, Steven A. 2005. Aquinas on Being and Logicism. New Blackfriars 86: 323-47. [CrossRef]

Lossky, Vladimir. 1957. The Mystical Theology of the Eastern Church. Translated by the Fellowship of St. Alban and St. Sergius. New York: St. Vladimir's Seminary Press.

Luibheid, Colm. 1987. Pseudo-Dionysius: The Complete Works. Mahwah: Paulist Press.

McDaniel, Kris. 2010a. A Return to the Analogy of Being. Philosophy and Phenomenological Research 81: 688-717. [CrossRef]

McDaniel, Kris. 2010b. Being and Almost Nothingness. Noûs 44: 628-49. [CrossRef]

McDaniel, Kris. 2013a. Degrees of Being. Philosophers' Imprint 13: 1-19.

McDaniel, Kris. 2013b. Existence and Number. Analytic Philosophy 54: 209-28. [CrossRef]

McGinn, Colin. 2001. Logical Properties: Identity, Existence, Predication, Necessity, Truth. Oxford: Oxford University Press.

McLean, Graeme R. 2015. Antipathy to God. Sophia 54: 13-24. [CrossRef]

Merricks, Trenton. 2019. The Only Way to Be. Noûs 53: 593-612. [CrossRef]

Miller, Barry. 1992. From Existence to God: A Contemporary Philosophical Argument. New York: Routledge.

Miller, Barry. 1996. A Most Unlikely God: A Philosophical Enquiry. Notre Dame: University of Notre Dame Press.

Miller, Barry. 2002. The Fullness of Being: A New Paradigm for Existence. Notre Dame: University of Notre Dame Press.

Moore, A. W. 2015. Being, Univocity, and Logical Syntax. Proceedings of the Aristotelian Society 115: 1-23. [CrossRef]

Moreland, James Porter, and William Lane Craig. 2017. Philosophical Foundations for a Christian Worldview, 2nd ed. Downers Grove: InterVarsity Press Academic.

Mullins, R. T. 2016. The Difficulty with Demarcating Panentheism. Sophia 55: 325-46. [CrossRef]

Nevitt, Turner. 2018. How to be an Analytic Existential Thomist. Thomist 82: 321-52. [CrossRef]

Oppy, Graham. 1997. Pantheism, Quantification, and Mereology. Monist 80: 320-36. [CrossRef]

Perl, Eric. 1994a. Hierarchy and Participation in Dionysius the Areopagite and Greek Neoplatonism. American Catholic Philosophical Quarterly 68: 15-30. [CrossRef]

Perl, Eric. 1994b. Symbol, Sacrament, and Hierarchy in Saint Dionysios the Areopagite. Greek Orthodox Theological Review 39: 311-56.

Perl, Eric. 2007. Theophany: The Neoplatonic Philosophy of Dionysius the Areopagite. Albany: SUNY Press.

Perl, Eric. 2010. Neither One nor Many: God and the Gods in Plotinus, Proclus, and Aquinas. Dionysius 28: 167-91. 
Perl, Eric. 2013. Hierarchy and Love in St. Dionysius the Areopagite. In Toward an Ecology of Transfiguration: Orthodox Christian Perspective on Environment, Nature, and Creation. Edited by Ecumenical Patriarch Bartholomew. New York: Fordham University Press, pp. 23-33.

Perl, Eric. 2014. Thinking Being: Introduction to Metaphysics in the Classical Tradition. Leiden: Brill.

Perl, Eric. 2019. Lessened by Addition: Procession by Diminution in Proclus and Aquinas. Review of Metaphysics 72: 685-716.

Pruss, Alexander. 2011. Actuality, Possibility, and Worlds. London: Continuum.

Rami, Dolf. 2014. Existence as a Property of Individuals. Erkenntnis 79: 503-23. [CrossRef]

Rhodes, Michael Craig. 2012. Mystery in Philosophy: An Invocation of Pseudo-Dionysius. Lanham: Rowman \& Littlefield.

Rist, John. 1967. Plotinus: The Road to Reality. Cambridge: Cambridge University Press.

Schellenberg, John L. 2005. Prolegomena to a Philosophy of Religion. Ithaca: Cornell University Press.

Schellenberg, John L. 2007. The Wisdom to Doubt: A Justification of Religious Scepticism. Ithaca: Cornell University Press. Schellenberg, John L. 2009. The Will to Imagine: A Justification of Skeptical Religion. Ithaca: Cornell University Press. Schellenberg, John L. 2013. Evolutionary Religion. Oxford: Oxford University Press.

Sprigge, Timothy Lauro Squire. 1997. Pantheism. Monist 80: 191-217. [CrossRef]

Steinhart, Eric. 2004. Pantheism and Current Ontology. Religious Studies 40: 63-80. [CrossRef]

Steinhart, Eric. 2017. Spirit. Sophia 56: 557-71. [CrossRef]

Stenmark, Mikael. 2019. Panentheism and its Neighbors. International Journal for Philosophy of Religion 85: $23-41$. [CrossRef]

Strawson, Galen. 2006. Realistic Materialism: Why Physicalism Entails Panpsychism. Journal of Consciousness Studies 13: 3-31.

Swinburne, Richard. 2010. Is There a God? Oxford: Oxford University Press.

Textor, Mark. 2017. Towards a Neo-Brentanian Theory of Existence. Philosophers' Imprint 17: 1-20.

Vallicella, William. 2014. Existence: Two Dogmas of Analysis. In Neo-Aristotelian Perspectives in Metaphysics. Edited by Davniel Novotny and Lukas Novak. London: Routledge, pp. 45-75.

van Inwagen, Peter. 2014. Existence: Essays in Ontology. Cambridge: Cambridge University Press.

Yamakage, Motohisa. 2006. The Essence of Shinto: Japan's Spiritual Heart. Translated by Mineko Gillespie, Gerald Gillespie, and Yoshitsugu Komuro. Tokyo: Kodansha International.

(C) 2020 by the author. Licensee MDPI, Basel, Switzerland. This article is an open access article distributed under the terms and conditions of the Creative Commons Attribution (CC BY) license (http://creativecommons.org/licenses/by/4.0/). 